\title{
百万塔製作技術の実験的研究 I
}

\author{
工作寸法 ; 輥轀の構造・精度と試作 ; 刃物と治具の適用
}

正会員成 田 寿一郎*

\section{1.はじめに}

法隆寺大宝蔵殿や東京国立博物館法隆寺宝物室に展示

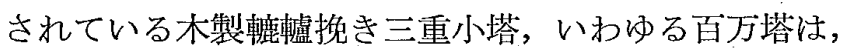
塔身内に収納されている陀羅尼経が，世界最古の印刷物 として有名であるが，塔自体もまた，形といい，仕上り といい，まことに見事な出来栄えで，ぼの塔一つをとっ ても立派な工芸的作品である。筆者は昨年夏, 遺物の塔 50 基を直接拝観し，寸法を実測する機会を得たが，そ の寸法・形状の整一さと，旋削仕上面の整った美しさ に，現代の技術に勝るとも劣らないものを感じた。しか もこの百万塔は個人的に熟練した名人芸による細工では なく，不特定多数の工人による一種の大量生産の所産で あるとされている。

これまで百万塔に関しては，塔内に収納されている経 文や，百万塔製作の時代背景などについて，江戸期に狩 谷杜斎・穂井田忠友, 明治末期に平子鐸䫛等の研究記述 があり ${ }^{1)}$ ，塔そのものについても，主要部の寸法，使用 樹種，さらに塔底面に残る墨書き文字から，製作年月掠 よび製作者名などについても若干の報告はあるが，塔を

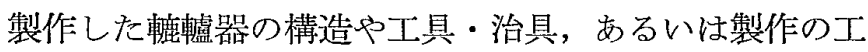
程や細部の技術的な諸問題などについての研究はほとん どない。

筆者は遺物の塔を仔細に観察し得たのを機会に，塔各 部の寸法を実測してその精度を確かめ，塔に残る刃痕と 使用樹種の材質との関係，塔各部の形状，とくに相輸細 部の仕上の状態などから，塔の旋削に用いたと思われる 軷裣の軸と軸受けの構造機能を，史料による考察を混え

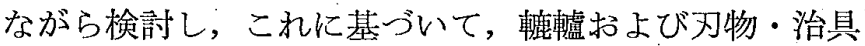
を試作した。この試作䡙僌㮩よび治工具によって, 遺物 と同じと思われる樹種を用いて塔を多数工作して一応の 成果を得，古代の木工加工，とくに旋削加工技術の実態 の解明に資することがでさたと思らので報告する。

\section{2. 史料による百万塔の製作経緯}

「続日本紀」巻第州称徳天皇の宝亀元年（770）4月の 頃に，かねて製作中であった小塔百万基の完成したこと

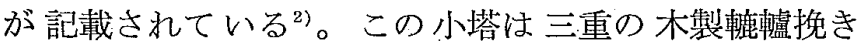
で3)，俗に百万塔といわ机，完成につれて法隆寺・東大

* 千葉大学 講師

（昭和 54 年 10 月 17 日本稿受理 ・討論期限昭和 55 年 12 月末日）
寺・薬師寺を始め, 奈良および近郊の十大寺に分置した とされているが4, 江戸末期にすでに法隆寺にのみ数万 基残っているが，他の諸寺のものはそれぞれ焼（消）失 してすでにないといわれていた ${ }^{5)}$ この塔は現在まだ法 隆寺に数万あるいは約 4 千基ばかり残っているといわれ るが，その数は定かでない( ${ }^{6)}$ 。しかし法隆寺蔵のうち， 小塔 100 基, 一万節溚および十万節塔各 1 基ずつ, 計 102 基が明治 41 年 1 月 10 日，国の重要文化財に指定さ れ，現在この 102 基は法隆寺大宝蔵殿に 展示されてい る。また法隆寺蔵のうち 48 基が, 法隆寺献納宝物の一 部として, 明治 11 年宮内省に献納され, 現在その 48 基注東京国立博物館法隆寺宝物室に 展示されている7”。

幕末から明治初期にかけての動乱期に，この塔の法隆 寺内より寺外に流出したものが多く, 現在市井において 古塔を時折散見する ${ }^{8}$ 。

昭和 36 年, 平城京跡上り未完成の塔身のみ 1 基発堀

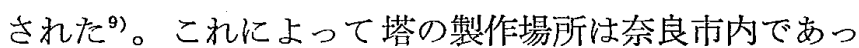
たことが推測されると共に，その仕かかりの状態から塔 身の旋削加工工程をうかがい知る手がかりとすることが できる。

塔の寸法について「続日本紀」には「高さ四寸五分, 基径三寸五分」とあるが，塔は上下二つの部分に分れ， 4.5 寸とは下部塔身のみの高さで, 上下合しての総高さ は約 7 寸である。上部の相輸は底部を丸䄲とし，塔身上 部中央にあけられた丸穴に嵌め込をれている。

使用した木材の種類については，塔身用材は桧である が，相輪用材は桂またわ水木犀（もっこく）といら説 と，桜であるといら節とがある ${ }^{10)}$

「東大寺要録」や「薬師持縁起」によれば，百万塔の 製作の孝謙上皇よりの下命は天平宝字 8 年 (764) 9 月 11 日に下されている ${ }^{11)}$ 。完成が「続日本紀」にある如く宝 亀元年 (770) 4 月と寸れば，小塔 100 万基の製作所要期 間は 5 年 8 箇月である。

百万塔の製作の進行過程についてはこれを知る手がか りになる史料がないので全く不明であるが，100 万とい う量から考光て下命後, 旋削の実際加工の開始までには かなりの準備を必要としかものと思われる。例えば，材 料である桧拉よび桂などの伐採・造材㧍よび伐採地より 製作工房所在地までの運搬，数十台あるいは百数十台に 
のぼると推測される較輼およびこれに伴う工具・治具な

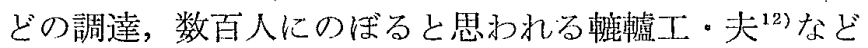
のための工房の建造などは，す心゙て下命後に始められた と思われ，それ等の準備調達のために相当の日数を費さ ざるを得なかったことが推測される。仮りにこの準備期

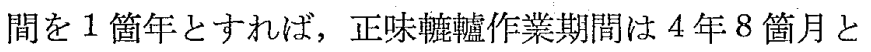
なる。天災・地変・吉凶などによる作業休止の日を勘案 して，1 箇月の平均稼動日数を 27 日と仮定して計算す れば， 4 年 8 䉪月で 100 万期を作り終えるには，1 日に 686 期，才なわち約 700 基ずつの生産を余儀なくされる ことになる。1 台の魙軑で 1 日何基の塔を作り得るか は，すべての条件を当時と同じにして旋削加工実験をし た上でなければ言及できないが，1台 1 日の旋削可能基 数はそれ程大きくなく，多数台の煄輜が每日稼動したこ とが推測される。「続日本紀」に「…事に供した官人己 下仕丁己上 157 人…」の記载があるが ${ }^{32)}$ ，この 157 人中 の官人と仕丁の人数比率, 仕丁の職種区分も不明で ${ }^{14)}$,

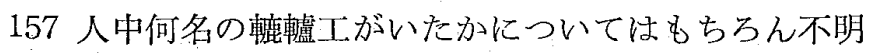
であるが，何れにしても数十あるい注百数十人の䡚䡷工 が毎日作業をしていたものと推測される。

\section{3. 遺物の工作寸法亡計測值}

東京国立博物館法隆寺宝物室所在の 48 基と市井所在 の 2 基計 50 基を，尺を直立させた台を作り，台上に位 置を定めて写真 1 のより塔を置いて $200 \mathrm{~mm}$ の望遠レ ンズで撮影をしこれを現寸大に引き伸したものについ て，図1のよらな測定简所を定めてその各部寸法をデバ イダで計測し，これを写真の添尺で読みとって各部の寸 法とした。層の内径 $\mathrm{c} \cdot \mathrm{d}$ は $\mathrm{h}$ 打よび $\mathrm{j}$ の中部部で求め た。三層座径bの測定のとき知損のあるものについては 写真上で半径を求めて 2 倍し, 两側に欠損のあるものに

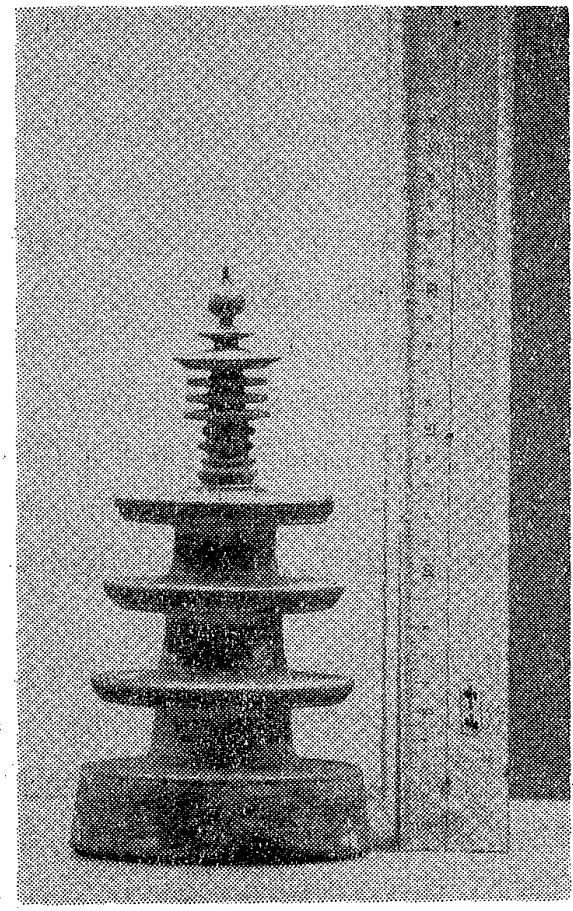

写真 1 . 寸法実測要項
ついては測定不能とした。なほ基台の直径 a，三層屋径 bについてはノギスによる実物測定も行い，写真測定と の平均值をその測定値とした。

相輪は欠損しているものがかなりあり，屋径や相輪間 隔にっいては測定不能の物も多かった。宋た塔の底面も 同じ要領で撮影し，材料の年輸閒隔や年輸の先行状態の 観察に供した。

各部寸法の実測值を表 1 亿，その平均值拉よび標準偏 差を表 2 に示した。また各部寸法の平均值に基づいた， 各部寸法図を図 1 亿示した。

䘚 1 百厅塔各部寸法実測值

(単位 $: \mathrm{mm}$ )

\begin{tabular}{|c|c|c|c|c|c|c|c|c|c|c|c|}
\hline No. & $\begin{array}{c}\mathrm{a} \\
\text { 斯台 } \\
\text { 径 }\end{array}$ & $\begin{array}{l}\mathrm{b} \\
\text { 三屬 } \\
\text { 屋 }\end{array}$ & 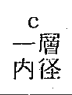 & 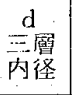 & $\begin{array}{l}\mathrm{e} \\
\text { 相鐱 } \\
\text { 屋佳 }\end{array}$ & $\begin{array}{c}f \\
\text { 塔身 } \\
\text { 高 }\end{array}$ & $\begin{array}{c}\text { 基台 } \\
\text { 高 } \\
\text { 简 }\end{array}$ & $\begin{array}{c}\mathrm{h} \\
\text { 層 } \\
\text { 間㜔 }\end{array}$ & $\begin{array}{c}\mathrm{i} \\
\text { 層 } \\
\text { 間隔 }\end{array}$ & $\begin{array}{l}\text { 兰層 } \\
\text { 間隔 }\end{array}$ & $\begin{array}{c}\mathrm{k} \\
\text { 㭗輪 } \\
\text { 隔 }\end{array}$ \\
\hline 1 & 104 & 77 & 43 & 34 & 37 & 134 & 32 & 32 & 32 & 34 & 36 \\
\hline 2 & 104 & 78 & 50 & 36 & 38 & 130 & 30 & 32 & 36 & 32 & 33 \\
\hline 3 & 106 & 77 & 49 & 35 & 38 & 127 & 32 & 32 & 36 & 33 & 33 \\
\hline 4 & 107 & 77 & 52 & 37 & 36 & 127 & 30 & 34 & 33 & 34 & 34 \\
\hline 5 & 102 & 77 & 46 & 36 & 35 & 133 & 32 & 34 & 34 & 34 & 32 \\
\hline 6 & 106 & 77 & 47 & 34 & 35 & 134 & 32 & 32 & 35 & 33 & 33 \\
\hline 7 & 107 & 77 & 47 & 37 & 37 & 129 & 32 & 34 & 33 & 33 & 32 \\
\hline 8 & 106 & 79 & 48 & 37 & 35 & 133 & 32 & 32 & 32 & 35 & 33 \\
\hline 9 & 100 & 76 & 44 & 36 & 38 & 1.32 & 32 & 35 & 34 & 32 & 31 \\
\hline 10 & 110 & 80 & 47 & 36 & 32 & 132 & 32 & 32 & 34 & 33 & 33 \\
\hline 11 & 108 & 79 & 48 & 33 & 38 & 132 & 32 & 34 & 33 & 33 & 33 \\
\hline 12 & 107 & 78 & $49^{\circ}$ & 36 & 36 & 132 & 30 & 35 & 33 & 33 & 33 \\
\hline 13 & 108 & 78 & 48 & 37 & 37 & 133 & 32 & 33 & 34 & 32 & 33 \\
\hline 14 & 106 & 79 & 47 & 36 & 36 & 131 & 30 & 35 & 32 & 33 & 34 \\
\hline 15 & 108 & 78 & 44 & 34 & 34 & 131 & 30 & 34 & 32 & 33 & 33 \\
\hline 16 & 107 & 78 & 48 & 38 & 38 & 132 & 32 & 35 & 33 & 34 & 34 \\
\hline 17 & 107 & 78 & 47 & 36 & 37 & 134 & 33 & 35 & 32 & 33 & 33 \\
\hline 18 & 107 & 77 & 47 & 37 & 37 & 133 & 30 & 35 & 34 & 35 & 34 \\
\hline 19 & 110 & 80 & 55 & 41 & 36 & 135 & 34 & 34 & 31 & 36 & 34 \\
\hline 20 & 108 & 79 & 47 & 33 & 33 & 134 & 32 & 33 & 34 & 33 & 33 \\
\hline 21 & 108 & 77 & 47 & 35 & 36 & 134 & 32 & 35 & 32 & 34 & 35 \\
\hline 22 & 106 & 76 & 50 & 35 & 34 & 131 & 32 & 33 & 34 & 34 & 34 \\
\hline 23 & 103 & 77 & 50 & 36 & 36 & 133 & 32 & 33 & 33 & 32 & 33 \\
\hline 24 & 105 & 79 & 49 & 36 & 36 & 130 & 31 & 33 & 36 & 32 & 33 \\
\hline 25 & 108 & 79 & 51 & 37 & 34 & 133 & 34 & 33 & 34 & 32 & 34 \\
\hline 26 & 109 & 80 & 48 & 35 & 35 & 131 & 33 & 33 & 33 & 33 & 33 \\
\hline 27. & 109 & 77 & 50 & 38 & 39 & 132 & 30 & 34 & 33 & 33 & 34 \\
\hline 28 & 106 & 80 & 47 & 35 & 34 & 132 & 33 & 32 & 33 & 32 & 34 \\
\hline 29 & $107^{\circ}$ & 80 & 44 & 35 & 33 & 130 & 31 & 35 & 33 & $33:$ & 32 \\
\hline 30 & 102 & - & 46 & 37 & - & 130 & 31 & 34 & 32 & 32 & - \\
\hline 31 & 107 & 81 & 48 & 36 & - & 131 & 32 & 33 & 33 & 33 & - \\
\hline 32 & 105 & 77 & 47 & 34 & 34 & 132 & 32 & 34 & 34 & 31 & 34 \\
\hline 33 & 108 & 78 & 47 & 34 & 35 & 133 & 31 & 35 & 34 & 33 & 33 \\
\hline 34 & 106 & 74 & 44 & 32 & 33 & 133 & 31 & 34 & 33 & 33 & 32 \\
\hline 35 & 105 & 79 & 44 & 37 & - & 130 & 32 & 32 & 33 & 34 & - \\
\hline 36 & 107 & 78 & 43 & 35 & 35 & 133 & 30 & 34 & 35 & 35 & 33 \\
\hline 37 & 103 & 74 & 45 & 32 & - & 131 & 31 & 35 & 34 & 34 & - \\
\hline 38 & 107 & 73 & 48 & 33 & 32 & 132 & 33 & 34 & 33 & 32 & 33 \\
\hline 39 & 106 & - & 47 & 37 & - & 132 & 30 & 34 & 31 & - & $\dot{-}$ \\
\hline 40 & 110 & 74 & 48 & 36 & - & 133 & 31 & 35 & 31 & 33 & - \\
\hline 41 & 107 & 77 & 46 & 34 & - & 133 & 32 & 35 & 35 & 33 & 33 \\
\hline 42 & 104 & 80 & 47 & 35 & - & 135 & 33 & 33 & 33 & 35 & 33 \\
\hline 43 & 107 & 76 & 48 & 34 & - & 130 & 33 & 33 & 33 & 31 & -- \\
\hline 44 & 106 & 76 & 46 & 35 & - & 131 & 31 & 33 & 32 & 32 & 34 \\
\hline 45 & 103 & - & 49 & 35 & - & 131 & 31 & 34 & 33 & 33 & - \\
\hline 46 & 107 & 80 & 49 & 36 & - & 132 & 31 & 32 & 32 & 33 & - \\
\hline 47 & 107 & 79 & 50 & 37 & $-\cdots$ & 132 & 33 & 33 & 33 & 34 & 33 \\
\hline 48 & 107 & 79 & 46 & 34 & - & 132 & 33 & 33 & 33 & 33 & 32 \\
\hline 49 & 106 & 77 & 48 & 35 & 34 & 134 & 31 & 33 & 32 & 31 & 34 \\
\hline 50 & 103 & 74 & 45 & 33 & 33 & 137 & 31 & 37 & 34 & 32 & 32 \\
\hline
\end{tabular}


表 2 各部平均小法扔よび標準偏差

(単位：mm)

\begin{tabular}{|c|c|c|c|c|c|c|}
\hline 測 & 定 & 部 & 位 & & 平均寸法 & 標準偏差 \\
\hline \multirow{5}{*}{$\mathrm{x}$ 方向 } & a & 基 & 台 & 径 & 106.3 & 0.215 \\
\hline & b & $\equiv$ & 層 屋 & 径 & 77.6 & 0.183 \\
\hline & c & - & 層 内 & 径 & 47.4 & 0.229 \\
\hline & d & $\equiv$ & 層 内 & 径 & 35.4 & 0.166 \\
\hline & e & 相 & 輪 屋 & 径 & 35.4 & $0: 182$ \\
\hline$\therefore$ & f & 塔 & 身 & 高 & 132.0 & 0.183 \\
\hline \multirow{5}{*}{$\mathrm{Y}$ 方向 } & $\mathrm{g}$ & 基 & 台 & 高 & 32.0 & 0.109 \\
\hline & $\mathrm{h}$ & & 層 間 & 隔 & 33.0 & 0.117 \\
\hline & $\mathrm{i}$ & $=$ & 層 間 & 融 & 33.0 & 0.119 \\
\hline & $\mathrm{j}$ & $\equiv$ & 層 間 & 隔 & .33 .0 & 0.107 \\
\hline & $\mathrm{k}$ & 相 & 輪 間 & 隔 & 33.5 & 0.101 \\
\hline
\end{tabular}

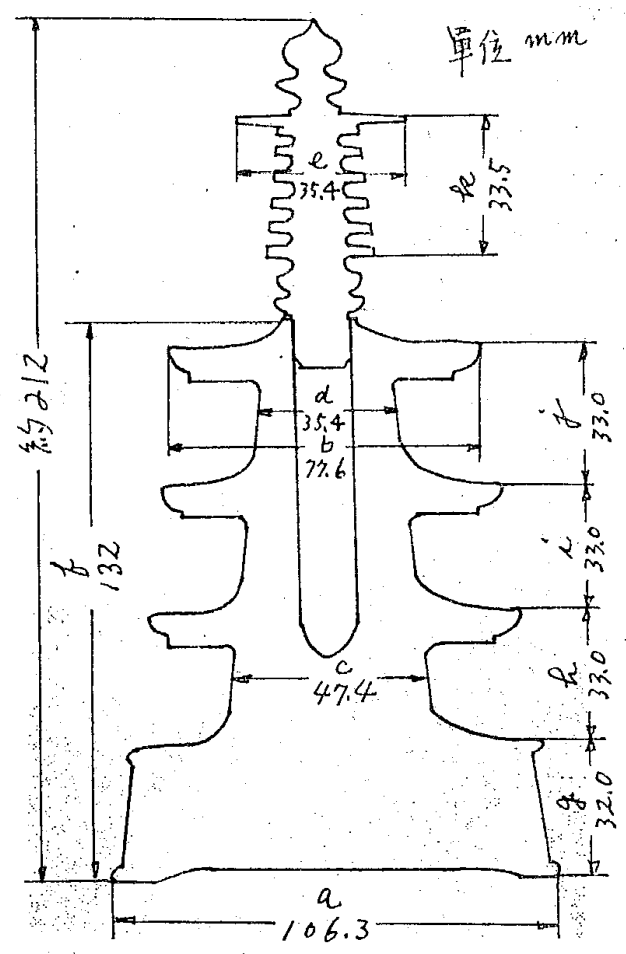

図 1 実測に基づく各部寸法图

「続日本紀」に記載されている 塔身の寸法は天平尺で あるとされている ${ }^{15)}$ 。そこで天平尺 1 尺を現矩尺 9.78 寸として換算し，さらにメートル寸法に換算すれば，塔 身の高さは $133 \mathrm{~mm}$ ，基径は $103 \mathrm{~mm}$ となり，実測平均 寸法は計画法に対し，高さに扔いてマイナス $1 \mathrm{~mm}$, 基径においてプラス $3 \mathrm{~mm}$ となり，とくに高さ方向の 実物平均寸法法計画寸法に対してきわめて近いことが判 る。

各部寸法の標準偏差は, 最大 0.229 , 最小 0.101 , 平均で 0.158 である。比較 のため現在市販されている

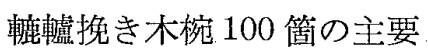
表 3 木椀の各部寸法㧍よび 標隻偏差 (単位 $: \mathrm{mm}$ )

部の標準偏差を表 3 に示し

\begin{tabular}{rr|r|r}
\hline \multicolumn{2}{c|}{ 測定部位 } & 平均值 & 標準偏差 \\
\hline 外 & 径 & 121.1 & 0.0324 \\
高 & $さ$ & 73.3 & 0.0618 \\
深 & さ & 55.0 & 0.0285 \\
\hline
\end{tabular}

たが ${ }^{16)}$ ，その平均值は 0.0409 であった。これに対し百 万塔のそれはやや大きいものの時代差を考えれば，塔の 工作精度の高さが確認されよう。

塔の直径方向の寸法をX群, 高さ方向の寸法を $\mathrm{Y}$ 群と
すれば，X群よりY群の寸法精度が一段と高いことが， 表 2 よりかる。とくに相輸の層階間隔寸法 $k$ の標淮偏 差は 0.101 各部寸法中もっとも精度が大である。これを 具体的にい光ば, 50 基の平均小法が $33.5 \mathrm{~mm}$ であり， $33.5 \mathrm{~mm} \pm 1 \mathrm{~mm}$ の範囲内に $92 \%$ ，すなわち 50 基中 46 基が拉さまるといら精確さである。

技術水準のいろいろ異なったであろら，多人数の工人 が,このような高い工作精度の作業を均しくなし得るた めには各立人に対し，単に寸法や図面を提示するのみで なく，現物模型や專用の治具・ゲー類を与えるなどの 方法が採られたものと推測される。とくにY方向の精度 がX方向のそ机に比して高いのは，Y方向の精度は挽き 込々始めの刃物の当て位犆で決悉るむので，その当て位 置の罴示には多爪買引形の割りつけゲージのようなもの が，挽き込み後の径寸法や形状の確認には形ゲージや深 さゲージ・㣣多ゲージのようなものが使われたのではな いかと推測される。そしてその治具・ゲー桜類は，作業 者個々に作らせたのではなく，中央の管理者側に扔いて 一括して同じものを多数作り，これを個々に作業者配 布してその使用を義務づける,すなおち加工技術の集中 管理方式が採られていたものと推測される。尚治具やグ 一類の設計や製作などは, 百万塔のデザインのものと 一緒に，中央管理者の技術スタッフとして椂工（た虬し こう ${ }^{100}$ の活躍があったのではないかと推測する。

\section{4. 被削面性状亡使用工具}

百万塔は木地完成後に，膠を糊料とした各色の顔料で 彩色されていたが，1200 年の今日それが㴽どてど剝脱 し ${ }^{18)}$ ，木肌を直接に見ることのできるものが多い。含回 測定し得た 50 基について，机的肉眼的観察扝よび手 持ちによる重量と觸感からみて，50 基すべての塔昼角 材は桧，相輪用材は桂であると判定するこどができる。

木肌面には，塔身・相輪共に，鑪・鮫皮・木賳(とく さ) ${ }^{19)}$ などによる研削痕がなく，また俗にキサゲあるい はナデシコ ${ }^{20)}$ などと呼ばれる仕上用刃物を使用した痕 跡も見当らない。塔身の側面 (直立) 部分には，ピツチ 約 $0.5 \sim 1 \mathrm{~mm}$ の浅樋状の整一な羽痕が，層階上下の水 平面には，ピツチやや不統一な細縞状刃痕が見られる。 相輪では宝珠先端部分に浅樋状とも縞状とも見える整一 な刃痕があるが，それ以外に刃痕はほとんど見られず， 全体としてきわめて整然とした，いわゆる鉋目も鮮やか な見事な出来栄えである。

これは，旋削作業に招いて，使用した䡚䡜器の精度が 高かつたことと共に，旋削される材料の材質と，旋削部 位の寸法と形状によっていろいろな刃物を使い分け，宗

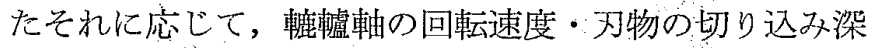
さ・送り速度などをがわめて合理的に駆使された結果の 所産であるとい完よう。

桧は同類の針業樹である杉や松に比べれば，春秋材部 
の硬軟差が小さく，質はかなり密であるとはいうもの の，やはり針業樹であり，全体として軽軟で，旋削性は 広葉樹の散孔材に比べてかなり悪い。したがって塔身の 旋削で用いる刃物は何よりもまず，刃先角が小さく，切 削㑇（刃先角と逃げ角の和）む小さくできるような，す なわち鋭どい刃先の刃物を用いばならない。をた軸の回 転が人力で，トルクが小さいから，1 刃当りの切削量も 制限され，したがってその刃幅も狭くせざるを得ない。 以上を勘案し，塔身側面の浅樋状の刃痕とを併せて検討 すれば，これを満足する刃物としては写真 2 に示すよう な小曲げ鉋刃以外になかったものと考元られる。また層 階上下の水平面は木口となるので, 1 刃当りの切り込み 量は更に制約されるから，刃先径を更に小さくした，小 曲げ鈎妇を用いたものと思われる。

相輸は被削径が小さいから，小曲げ鉋刃では切削角の 微妙な調整がとりにくく，ややもすれば刃先が材中に飡 い込んで衝撃のため材のとりつけがゆるみ，旋削不能と なる恐れがある。したがって小曲げ鉋刃の使用はきわめ て難しい。しかし桂浪広 葉樹散孔材で, 材質注均 一で，桧に比べて旋削性 が良いから，刃物の切削 角はかなり大きくても被 削肌はそれ程粗にならな い。したがって相輪の旋 削には，小曲げ鉋刃に代 えて鑍状刃物を用い, 一 刃当りの切り込み量を小 さくして旋削したものと 思われる。

遺物の奏測による相輪 の寸法図を図 2 に示し

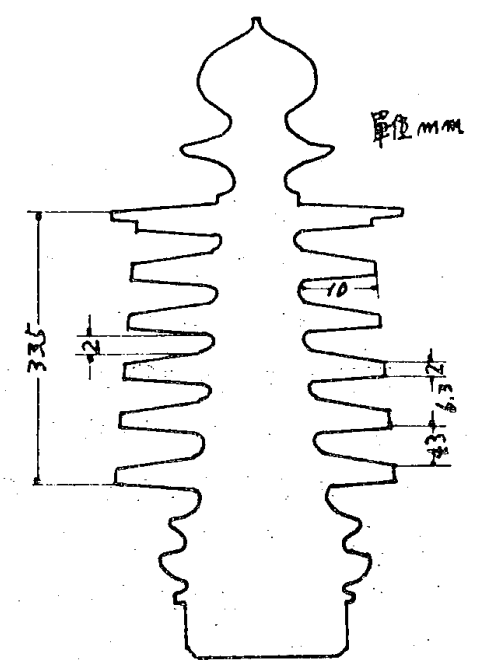

図 2 相輸寸法実測図
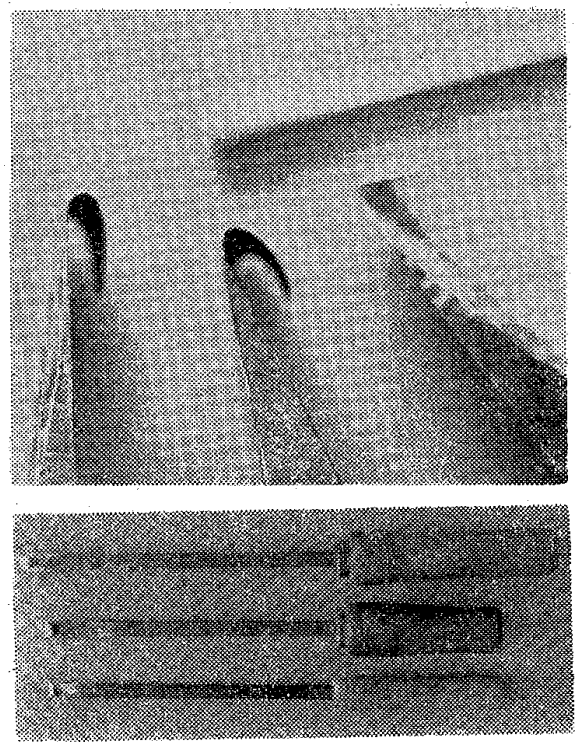

上部の白棒はマッチ軸木

写真 2 小曲 げ鉋刃
た。層間ピツチは平均 $6.3 \mathrm{~mm}$, 各層間のもっとも狭い 部分が $2 \mathrm{~mm}$ で，深さは約 $10 \mathrm{~mm}$ である。このような 狭い部分を精確にかつ久損なく旋削するには，刃幅 1〜 $1.5 \mathrm{~mm}$ の向待ち形の䍈（刃幅が挟く, 厚さの大きい穴 堀り専用のもの)でなければならない。この整状刃物を 写真 3 に示した。

塔身の上部中央に，経文を収納しかつ相輪基部の丸䄲 を嵌めるための媣い丸穴が垂直に㐫けられている。遺物 の塔 23 基について穴径掞よび深さを測定した結果を表 4 亿示した。穴径はかなりバラッキが大きく，穴の側壁 む横削りの痕跡がみられ，かなり粗であった。穴底の形 状は弾頭形をしていて, 中央部に一段深い凹みらしきむ のが見られるものが 23 基中約 10 基あった。このよう な状態から穴明けに用いられた工具は, 揄れ雓や鍽（も

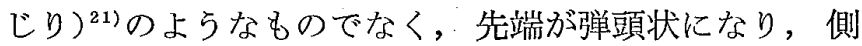
刃穵もった匙錐（写真 4) あるいは板錐が用いられたも のと推測される。穿孔作業はもち万ん加工物を回転さ せ，錐を押し込むものであるが，網引き回転ではトルク が小さいから $20 \mathrm{~mm}$ 以上もの径の錐を一挙に押し込む ことはできない。始めに 8 10 $\mathrm{mm}$ の小径で穴をあけ， 15 17 mm の中径を経て最後に目的径の錐を押し込む。
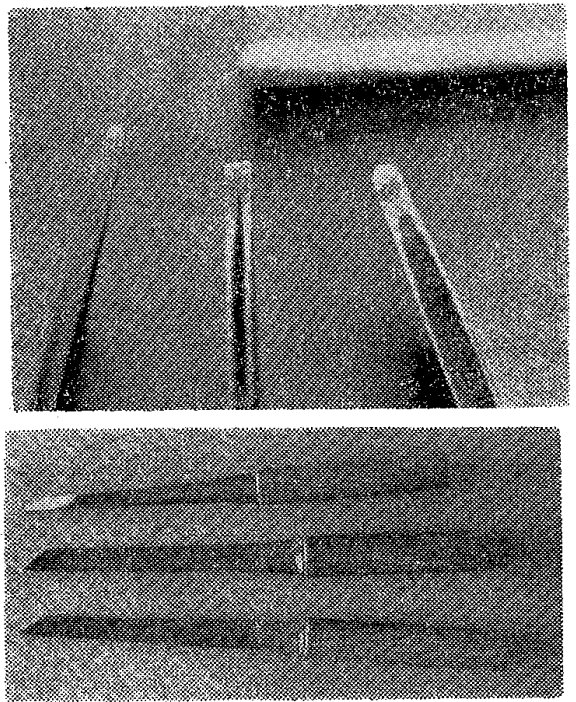

写真 3 鳌成

表 4 穴 0 状沉

(単位 $: \mathrm{mm}$ )

\begin{tabular}{c|c|c|c|c|c|c|c|c}
\hline No. & 穴 径 & 深 さ & No. & 穴 径 & 深 さ & No. & 穴 径 & 樑 さ \\
\hline 1 & 20.4 & 85.7 & 9 & 21.4 & 88.5 & 17 & 22.0 & 80.8 \\
2 & 21.2 & 86.0 & 10 & 25.7 & 90.2 & 18 & 24.1 & 79.2 \\
3 & 20.2 & 94.8 & 11 & 21.4 & 95.2 & 19 & 22.8 & 87.2 \\
4 & 17.8 & 91.7 & 12 & 20.4 & 93.0 & 20 & 23.0 & 80.4 \\
5 & 21.6 & 93.3 & 13 & 23.6 & 85.3 & 21 & 21.0 & 91.7 \\
6 & 20.8 & 77.0 & 14 & 24.0 & 76.8 & 22 & 22.5 & 81.6 \\
7 & 21.6 & 87.2 & 15 & 23.3 & 93.0 & 23 & 21.0 & 80.0 \\
8 & 21.4 & 81.6 & 16 & 21.0 & 70.9 & & & \\
\hline
\end{tabular}

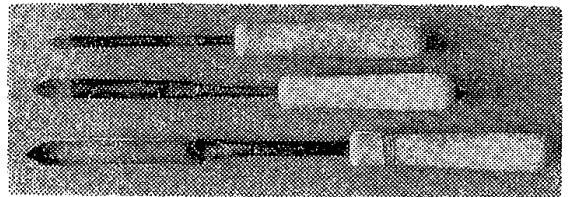

写真 4 题 状錐 
穴底中央部に一段深い叫みのあるのは最初の小径錐が少 し深すぎるためのものであるら。穴径は最後に用いる錐 径できまるが，穴径にバラッキがあるのは，錐径にバラ ツキがあったことを示している。しかし回転中の軸振 れ，あるいは錐の側刃の切味不良などで穴径が 1 2 mm の範囲でバラックことはあり得るが，表 4 でみるごとく 穴径は最小 $17.8 \mathrm{~mm}$, 最大 $25.7 \mathrm{~mm}$ で, その間 $1 \sim 2$ $\mathrm{mm}$ の差のものをグループ別にまとめると, 17〜 18 mm, 20〜22 mm, 22〜24 mm, 24 25 mm の 4 種類の異った 径の錐が使われたものと推測できる。

以上述べたごとく, 百万塔の旋削には, 塔身用として 小曲げ鉋刃と匙錐または板錐状刃物, 相輪用として小幅 蔹刃を用いたと思われるが，これらの工具は，形状とい い, 寸法といい, きわめて特殊なもので, 一般の建築木 工や指物木工用のものとは完全に異なるものである。現

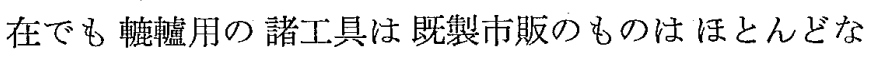
${ }^{22)}$, 工人が鋼棒の形で購入し, 自ら鍛造・成形・焼入・ 研磨をして使用している状態で，このことは江戸期にお

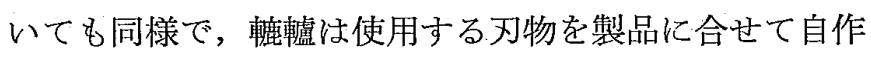
することを得て，始めて一人前とされたものであるる3 奈良時代に抢いてどらであったかは，文献・記録の上か らは知る術もないが，現代扔よび江戸期の慣習の起源は 奈良時代まで遡り得るのではないかと推測される。この 場合小曲げ鉋刃や䌘刃では若干の寸法違いは製品にあら われないが，穴用錐だけ甶各個人による寸法違がそのま ま穴径のバラッギとなっであらわれたものと推測するこ とができる。

\section{5. 㢑䡙の構造・機能}

(1) 史料による考察

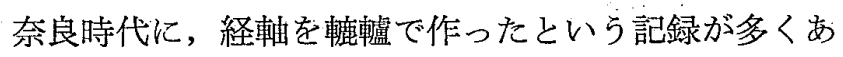

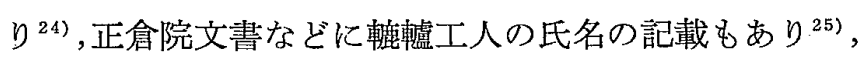
正倉院の御物木工品中に明らかに䡙轀挽きと思われる香 合などもあるから ${ }^{26)}$, 同時代に輤轀があって，これを駆 使する専門技術者がいたことは明らかであるら。しかし 同時代の史料に，轞轀の構造・形式について説明したも のはほとんどない。ただ「正倉院文畫」に「六斗二升瘘

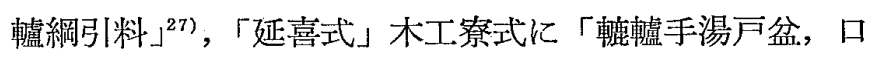

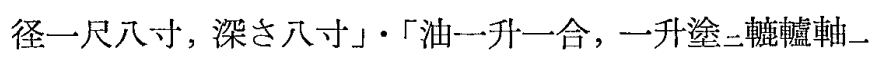

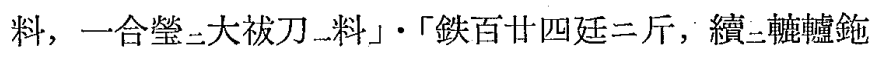
刃_料，並造二充諸司雑鉄物料」などの記載があり，こ

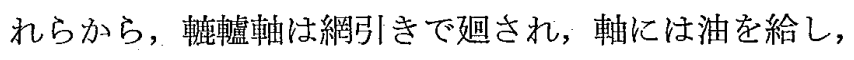
刃物恃鉄で鉇状に作り，直径 1.8 尺もの大きなものを挽 くこともあった。などのことが断片的に分るだけであ る。

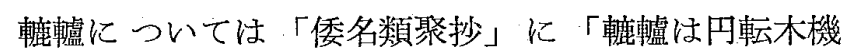

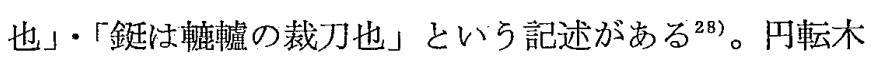
機といら語の解粎にはいろいろあるが, 裁刀の 2 字から

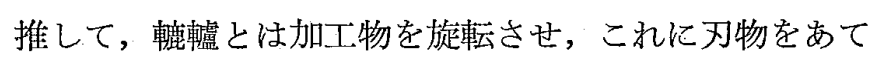

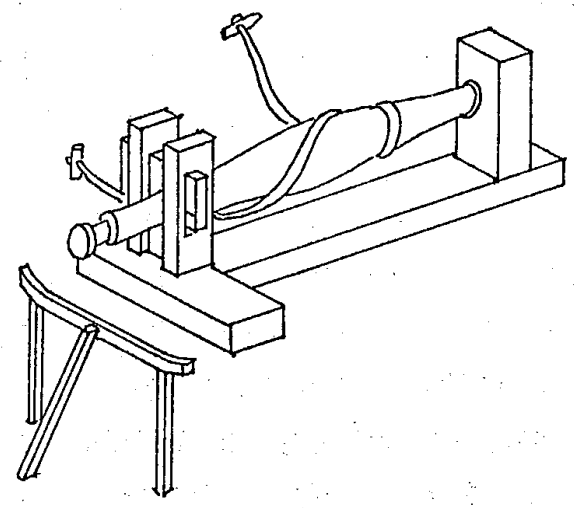

図 3 「和漢三才図絵」所載の轆轤

て裁く，すなわち旋削して目的の形を作るものと理解す ることができる。鋌の字については「笺註倭名類聚抄」 に「按木工寮式所載䡡轀鉇即此…中略…広韻又云鍦, 鍦 作程同謂二以縄転レ軸木為レ器者一也㥺鍦以二旋転一為一各

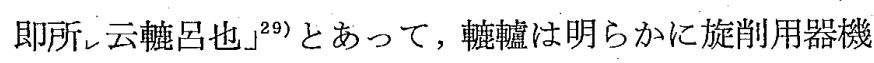
であり，鋌は鍦であり切削用工具であることが判る。中 国後魏の「斉民要術」に「挟者鍦作獨楽及蓋一䈏三文 …後略」とあり ${ }^{30)}$ ，鍦で獨楽や蓋を作るとあるからには

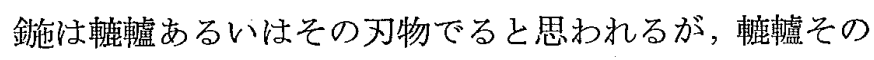
ものの形式・構造についてはなほ不明である。

江戸期に入って「訓蒙図彙」・和漢三才図絵」の二書 に軧僌の構造をらかがわせるに足るやや精巧な図があ る ${ }^{31)}$ 。「訓蒙図菓」ではこれを搴鑽，「和漢三才図絵」で は車鋌といっているが; 両書に描かれた図恰全く同じで 亦当 (図 3 )。「訓蒙図彙」は宽文 8 年 (1668)，「和漢三 才図絵」は正徳 2 年 (1712) の成立であるから, 後者の 図は前者の模写であることは明らがである。後者の解説

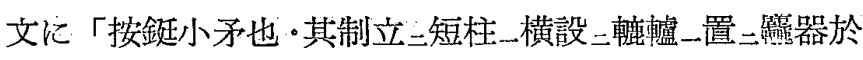
耑_有二革紐一人以左右旁転之一人持レ鋌削し器」とあ り，形式と機能むやや詳しく説明している。しかしこの 説明によって図 3 を考察しても, 軸受讨は首部 1 箅所の みで，尾端柱軸床凸起部に丸柿で嵌められていることは 判るが，その細部はなほ不明である。

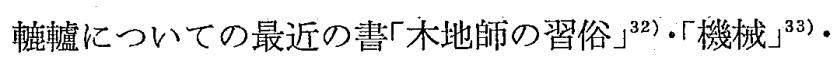

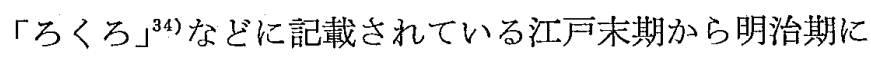
かけて使用された轠䡷の写真や実測図をみても, その形 式・構造は図 3 と大同小異である。

このような構造の轆䡴では，軸の振れは規制し得て も，軸の軸方向の動きを規制することは難しい。すなわ ち正面挽き（軸端方向から物をあてて削る方法, 縦挽 きともいら）はできても, 百万塔の, とくに相輪の形状 のような側面挽き（横挽ともいら） は不可能か, もし可 能だとしても,きわめて高度な熟練者が慎重に作業した 場合に限られよう。

しかるに遺物の塔身および相輪を観るに，その工作寸 法精度がきわめて高く, とくにX方向よりY方向の寸法 精度が高いことは，使用した癄轤の，軸振れはもちろ 
ん，軸の軸方向の動きがほとんど皆無であった ことを物語るものであり，図３で見るよらな棈 造形式のものでは長期の使用に垷えなかったの ではないかと推察される。

(2) 中世以降の䡶䡷の軸と軸受计構造

轆䡷の器械としての主要部分は, 加工物をと りつけて回転させる軸と，それを支えて，正 確・円滑かつ軽快に 回転させる軸受けとであ る。中世以降の絵巻物類あるいは絵図類にあら われた軸および軸受けの形式・構造について考 察すると次のよらである。

a. 軸…長さ約 $500 \mathrm{~mm}$, 直径約 $50, \mathrm{~mm}$ の丸 棒で，硬木製（多くはミネバリ材）である。軸 の形式には平行式と中太式の三種がみられる が35), 現在する江戸末期および明治期のものは すべて平行式で，中太式のものはない。中太式 は旁綱が常に中央に集るといら利点はあるもの の，実用上の効果にあまりない。

軸の持つべき機戌的条件として，軸線が真直で，断 面，とくに軸受けに支えられる部分が真円でなければな らない。このよらな丸棒は旋削によって作られねばなら ぬが長さ $50 \mathrm{~cm}$ にすなれば片持ち式の畽輼ではとりつ けがいかに強固でも加工材の端末が振れて旋削は不可能 になる。

これを補うためには心押し機構に匹敵する何等かの補 助装置の必要を痛感させるものがある。また百万塔の相 輪の穻珠先端に到るまての整一で見事な旋削痕から推し て, そ, その旋削には相輪底部の丸柄の径の正確さとある程 度の長さを必要とするが：(相輪の旋削工程については後

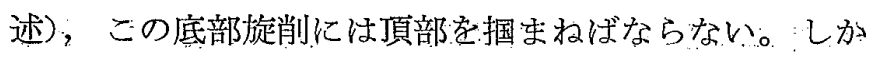
し相輪材は桂であり，やや硬質で，しか子塔身程の大径 の木取り寸法情えられぬから取付爪は塔身の時のよら に大径深爪・[6-(3)] の方法を採れず小径浅爪式とせざ るを得ずその保持力は小さくなり，この場合も前述の長 い回転軸の場合と同様に心押し装置状の何かが必要であ ると推測せざるを得ない。しかし中世以降の輤䡷に関す る文献類には直接に心押し装置の存在を示晙する何物も ない。ただ起源は分らぬが軝䡷設備の一つとして軸と同 一の線上にあるジクネンボウ ${ }^{36)}$ が心押し機構の一つの祖 形と考えられるがその事については尚考登と研究調查を 必要とする ${ }^{37) 。}$

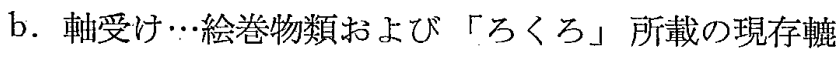
輼（年代は不明であるが何れも江戸末期の物を思われ る） ゆ実測図より軸受けの構造形式を抽出して整理し， これを表 5 に示した ${ }^{38)}$ 。表 5 で軸受けの機能を不完全な がらも果していると思わ狄るのは，軸を二つの材で上下 から押えている BとDで（Dの構造は図 3 と同じ，“ $A$ とCは軸と軸受け板をどのようにして組立てが疑問が
表 5 軸受けの構造形式

昭和 53

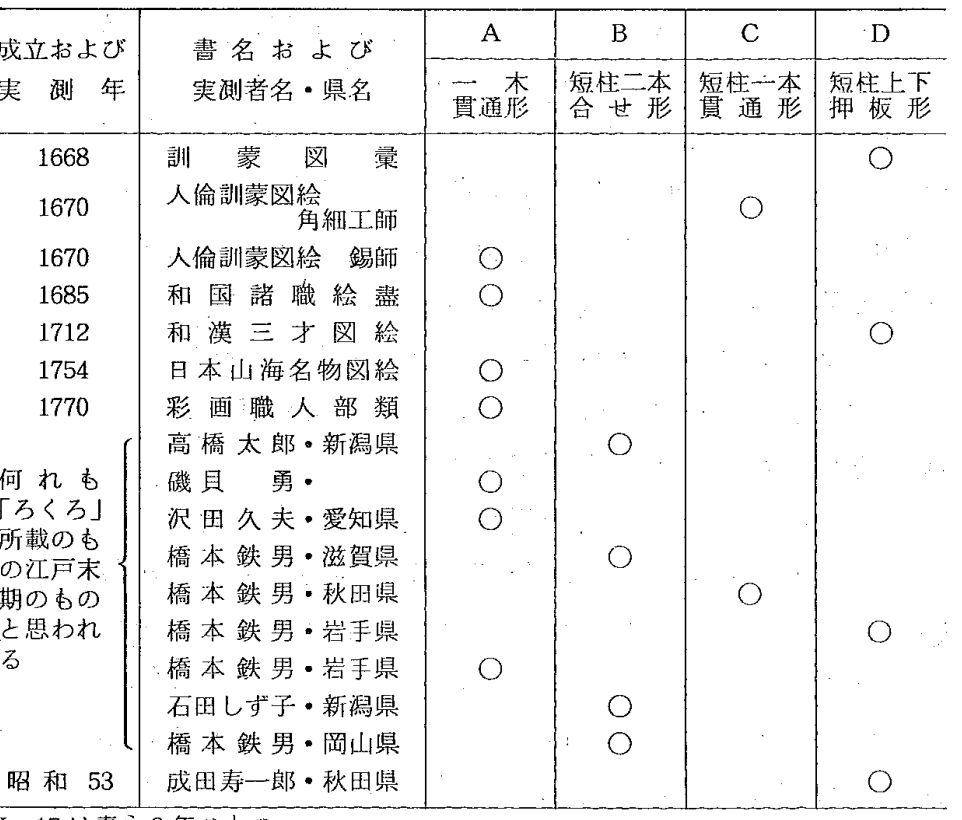

あり，全くの絵空事としか受けとれない。

軸と軸受けの直接接触部はいくら給油しても，長期間 の運転をすれば摩耗して遊隚を生じ, 軸振れおよび軸方 向の動きを助長する。この遊隚を補正し, 常時正確な回 転を維持するためには, 軸受け部あるいはとの他の部分 に何らかの摩耗調整のしくみを持っていなければならな い。表 5 のらち，Dは軸振れを調整するしくみを持って いるように見受けられるが，他には見受けられない。

このような軸受け構造の轆轠では, 百万塔, とくに相 輪の旋削は不可能であるといわねばならない。

c. 加工材の軸えの取りつけと軸受け構造

遺物の塔身底面を観察すると，塔身を軸端にとりつけ た爪の打ら込み跡がみられる。们の数は 3 ないし 4 本で 深さは実測の結果いずれも 25〜28 $\mathrm{mm}$ である。これだ けの長さの爪を 3 ないし 4 本と同時に底面光打ち込むに は，たと无塔身材が桧で軟質であっても，軸を軸受けに 組みこんだままでは, 打ち込みの衝撃のため軸受けは破 損してしまう。したがって加工材を軸え打ち込むとき は, 軸を軸受けより外して別の場所で行わ秝ばならな い。この意味で軸は軸受けに効し，簡単に分解・組立で きるしくみでなければならない。

\section{6. 百万塔旋削可能な轆䡷の試作}

\section{(1) 試作魙轀の構造}

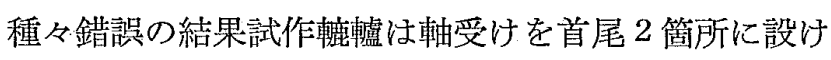
た。軸受け構造は表 5 Dのよらに短柱をたて，上下の押 え板で軸を支持するようにしたが，軸振れを少くするた めに上部押元板を，軸受け板押光棒と楔により軽く下圧 する方法を採うた。また軸方向の動きをなくすために， 首部軸受け部にあたる軸部に段久きを設け，軸受け板で これを受けて軸の首部方向えの移動をとめ, 軸の尾端か ら軽くこれを押すようにした。押す方法としては, 軸床 
凸起部に作った立形の溝に楔を落す方法を採った。尾部 軸受けは平受けとした。軸受け板と軸, 軸端と楔の接触 部㹥るるへく小面積として摩擦抵抗を小とし，軽快に回 転するようにした。

接触各部が摩耗して遊隙ができれば，楔が働いて自然 に摩耗調整機能を果してくれる。

この構造によれば，軸のとりつけ，とりはずしはきわ めて簡単である。

試作轆轀の構造図およびその姿を，図 4 および写真 5 に示した。

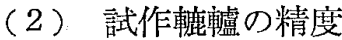

機能拉よび精度の良否を比較するために，軸受けが首 部 1 箇所，軸端を軸床凸起部に嵌め込みのものを作りこ れをA機とし，軸受け構造を図5 のようにした。図4の 軧輼器を $\mathrm{B}$ 機とし, $\mathrm{AB}$ 両機の軸の静的精度を JIS 規 格中丸ノコ盤の精度検查 ${ }^{39}$ を準用し，製作直後と， 2 時

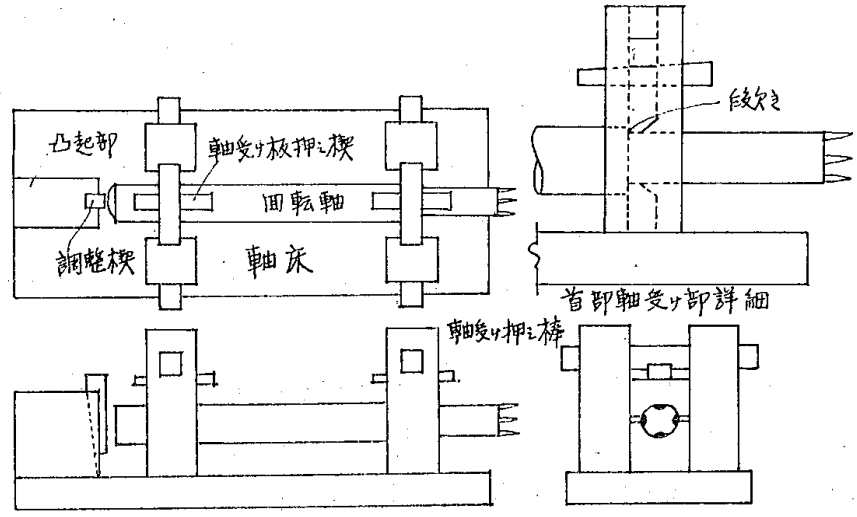

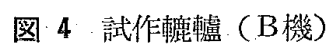

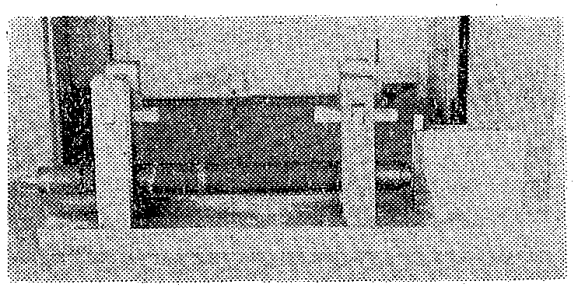

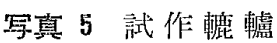

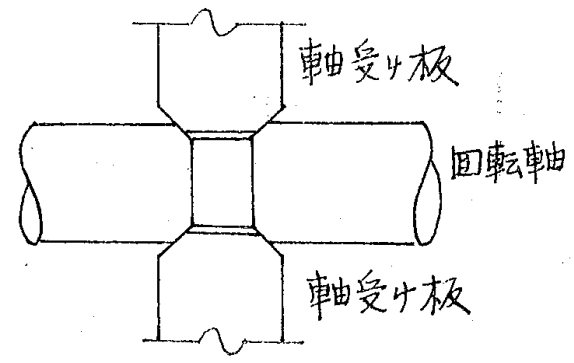

図 $5 \mathrm{~A}$ 機の軸受け丵造

言 6 精度検香結果

(単位: $\mathrm{mm}$ )

\begin{tabular}{|c|c|c|c|c|}
\hline \multirow{2}{*}{ 機（器）種 } & 初期の軸の & 初期の軸の & 2 時間後の & 2 時間後の \\
\hline & 振机 & 軸方向の動 & 軸の振れ & $\infty$ 動 き \\
\hline 精密級丸ノコ盤 & $(0.02)$ & $(0.03)$ & - & - \\
\hline 並級丸ノコ盤 & $(0.03)$ & $(0.08)$ & - & - \\
\hline A 器 & 0.08 & 0.09 & 0.4 & 0.6 \\
\hline B 器 & 0.06 & 0.08 & 0.07 & 0.08 \\
\hline
\end{tabular}

間の連続回転の 後とに 分けて 精度測定をし，その結果 を，表 6 と示した。両機共初期の精度は，軸振れ・軸動 き共に $0.1 \mathrm{~mm}$ 以下で, 精密丸ノコ盤に比し約 3 倍で はあるものの，百万塔製作用轅輑としては充分な精度を 有している。しかし 2 時間運転後の精度はA機では初め の 4 5 倍にむなり, 塔製作用, とくに相輪旋削用とし ては使用不能に近い状態になった。それに比べてB機の 精度はほとんど変らなかった。分解して段欠き部を見る とかなりの摩耗の跡が見えるが，軸端よりの楔の調整の 效果があったものと思われる。

（3）加工材のとりつけ方法

百万塔の 旋削に おいて，完全正面挽きがなされるの は，塔身の穴明けと底面の旋削だけで，他の部分および 相輸はすべて 側面旋削である。側面旋削は加工物に 刘 し，刃物の側面圧力がかかるため，加工物の実えのとり つけはとくに強固でなければならない。

塔身の 側面旋削 および穴あけのさの軸えのとりつけ は，塔身底面に残る爪跡から，長さ $25 \sim 28 \mathrm{~cm}$ の爪が 打ち込まれたものと判る。しかし東博所在の 48 基中,

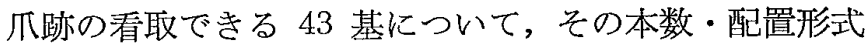
および開き寸法を調べると表 7 のように非常にまちまち

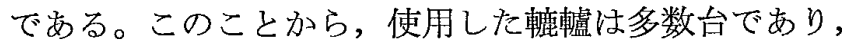
しかもその軸爪はかなり多人数の別々の工人によって製 作されたものであるうと推測することができる。

塔身底面の旋削は，先にあけられ丸穴を利用し，軸端 に枋を作って，穴をこれに差し込んで行ったすのと推 測される。

遺物の相輪に爪跡は見られないが，相輪の形状と宝珠 先端に到るまでの見事さから推して，そのとりつけはよ ほど強固なものであったと思われる。これには，はじめ に相輸基部に丸柄を作り，この丸移孛，軸端に作った丸 穴にきつく炭めて回転させたものと考えられる。その丸 柄を作るには，末旋削の宝珠部分を，爪の方法で軸にと りつけることが考えられるが，相輪材は桂であって，桧 より硬く，割裂性も大きいから，塔身の場合の上うに，

表 7 爪の形と閶き寸法

(単位 : mm)

\begin{tabular}{|c|c|c|}
\hline 形 & 名 称 & 開＜wide>き～寸 \\
\hline$-1-$ & 十 字 形 & $19,20,23,24,25,27,31,46,48,52,66$ \\
\hline I & 箱 形 & $15,20,21,24,24,38,42,42,44,52,56$ \\
\hline- & 菱 形 & $22,22,28,33,48,50,50,52,54,57$ \\
\hline 11 & 斜 菱 形 & $22,25,53,56$ \\
\hline $\begin{array}{l}-\cdots \\
--\end{array}$ & 二 列 形 & $32,39,40$ \\
\hline 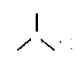 & 外三角形 & 28,44 \\
\hline $\overrightarrow{11}$ & 内三角形 & 52 \\
\hline- & 菱二 列 形 & 40 \\
\hline
\end{tabular}




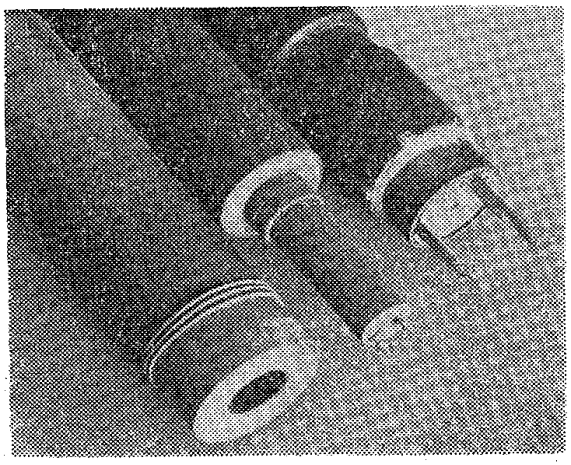

中央のものは小爪：丸枘萧用

写真 6 軸のとりつけ形式

大爪を深く打ち込むことはできない。したがって，爪は 長さ $5 \sim 10 \mathrm{~mm}$ ，開き寸法 10〜20 $\mathrm{mm}$ 位でなければな らぬが，それでは保持力が弱いので，これを補完する意 味で，5-(2)-a で述べたよらな心押し装置の併用が必要 であったものと推測する。心押し装置については塔の試 作奏験の項で詳述する ${ }^{37)}$ 。

以上のように百万塔の旋削加工のさいの加工材の回転 軸えのとりつけ方法として，塔身用には大爪式と丸枋嵌 め込み式，相輪用としては小爪と丸穴差し込み式が必要 となる。試作した 4 つの形式のものを写真 6 亿示した。

\section{7. まとめ}

百万塔は日産約 700 基といらノルマ的性産を余儀なく されていたと推測されるにも拘わらず，その出来栄えは 誠に見事である。筆者は遺物の塔約 50 基を仔細に観察 し，各部の寸法を実測し，それから推して塔の旋削技術

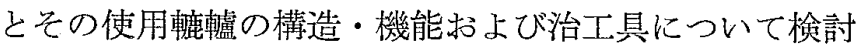
を加えたが，結果は次のとほりであった。

（1）実測平均小法は「続日本紀」に記されている計 画寸法にきわめて近い。

（2）各部抾の標準偏差は, 平均約 0.15 で，とく にY方向，すなわち高さ方向の工作寸法精度が高 w。

（3）塔身および相輸の表面に残る整然とした刃痕 と, 工作寸法精度の高さとを合せ考えて，使用䡆 轀はきわめて高精度で, とくに軸の軸方向の動き の小さい構造のものであったことが推測される。

（4）塔身の穴，基台底面の旋削痕はかなり乱れてい るが，このことから穴あけ用工具と，底面旋削に おける，塔の軸えのとりつけ方法が推測される。

（5）塔身抒よび相輸用材の材質と，そ水ぞれの被削 面に残る刃痕形状加ら，塔身の側面旋削には小曲 ゲの丸刃を，木口面には小曲げの鈎刃を，相輪の 旋削には蕶刃を，とくに階層の挽き込みには幅 $1 \sim 1.5 \mathrm{~mm}$ の向待形鳘刃を用いたことが 推測さ れる。穴女けには赽状錐をたは先端が弾頭状の板 錐の使用が推測される。

（6）无物の当て位置鞼示には, 跿引き形の割りつけ
ゲージを，旋削結果の寸法や形状の確誌には，形 ゲージや深さゲージなどとが用いられたと推测さ れる。

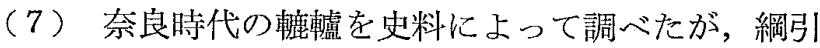
きで，軸に給油した，などの外にその構造・機能 については不明である。

（8）中世以降の㾟轀を絵図・実測図その他の資料に よって調べたが, そのほとんどが軸受けの棈造形 式から推して, 軸の軸方向の精度が低く，百万塔 旋削用には不適当と思わ水た。

（9）以上の考察に基づき，軸受けを首尾 2 箘所に設 け，軸に作った段久きと調整楔とによって，軸の

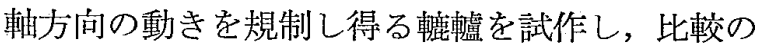
ため在来形稪轤との 2 機を, JIS 規格を準用して

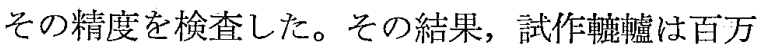
塔, とくに相輪を旋削するにも必要にして十分な 精度をもつものであることが確認され，塔の試し 旋削の結果汃らもその事吕確かめられた。

（10）遺物の塔の形状・寸法および旋削刃痕などから 推して，加工材の軸えのとりつけには，大爪式 • 小爪式 (心押し装置併用) - 丸柄式 - 丸穴式の 4 つの方法が採られたものと推測され，この4つの 軸を試作した。

以上百万塔の遺物について種々観察・調查した結果に 基づき，使用したと思われる軷㠊や治・工具について検 討を加え，試作して試用した結果を報告した。

引き続き次報では，実さいに旋削作業を長期にわたっ て行い, 塔を試作し，その結果に基ついて技術上の諸問 題や製作工程などについて検討し，また 1 基あたりの旋 削所要時間から割り出した実さいの旋削作業体制につい て検討したい。主た使用した樹種・性状, 採材方法およ び使用量などについても検討を加え，百万塔 100 万基生 産の技術的全容を明らかにし，これを報告したい所存で ある。

\section{謝辞}

本研究に当って, 百万塔遺物の観察・測定の便宜を与 えられ，かつ多くの資料を供与下された。東京国立博物 館, 法隆寺宝物室長, 文部技官木内武男氏, 史料を供与 され, 種々御指導下された, 千葉大学工学部教授大河直 躬氏，技術的助言と木椀測定などに協力を賜った，小田 原の神奈川県立工坛指導所, 刃物製作に協力下された兼 房刃物工業株式会社, 長野県南木曾の挽物業界の方々に 深甚なる謝意を表するものである。

\section{注}

1）狩谷掖斉「続日本紀校注」。穗井田忠友「観湖雑帳」「平 子鐸嶺「百万塔肆改」明治 41 年等

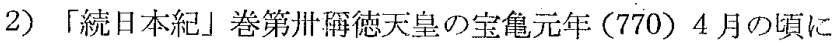
「戊午初天皇八年乱平乃発二弘願一令造二三重小塔一百刀 基一高各四寸五分基徍三寸五分露盤之下各置 根本袐心相 
輸六度等陀羅尼二至レ是功菑分二置諸志一賜二供レ事官人己 下仕丁己上一百五十七人爵 各有レ差」とある。

3）「諸寺緣起集」菅家本の元興寺吉祥堂の條に「……故号小 塔院，廤轤曳高七寸許塔也」とある。

4）平子鐸嶺は十大寺とは「拾芥抄」にありとして，「百万塔 䣃收」に次の 10 大寺を挙げている。大安寺・元興寺・興 福寺 - 薬師寺 - 東大寺 - 西大寺 - 法隆寺 (以上奈良) 四天 王寺 (攝津) 崇福寺 (近江) 弘福寺 (大和)。

5)「観湖雑帳」前揭書に「百万塔, 今法隆寺に幾万識加残

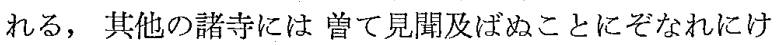
り」とある。

6)「百万塔疑改」前揭書に「今法隆寺に伝5るもの万有余」・ 「百万塔の今寺に存するむの四万三千九百三十篭」の $2 つ$ の記載がある。また 東京国立博物館法隆寺宝物室長木内 武男氏によれば（今法隆寺に存するもの約 4 千基）という が，その残存実数は不明のようである。筆者は本稿で， 一夋木内説学採った。

7） 48 基中常時展示されているものは 20 基，28 基は別に保 管されている。

8）幕末から明治にかけてと，第二次大戦後若干の期間の 2 回にわたり寺外に対してかなり流出したといら。現在に 市井に 奈良時代作の古塔と思われるものを私有している 人がかなり多い。但し昭和 14 年の模作も多い。

9）「奈良国立文化財年報」1966 未完成小塔塔身 1 基，篎旋 削挽込み。穴拉よび底面未加工。

10）「百万塔肆砇」前揭畫に「塔身法, 相輪㤬桂をた小水木 犀。狩谷掖斉は「続日本紀校註」に「……其露盤以上用 桜，以下用桧」とある。

11）「東大寺要録」第四本願章, 薬師寺本「楽師寺縁起」元弘 三年 (1333)。

12）綱引き轀轆の綱引き工のことを「正倉院文書」なじでは夫 と記している。

13) 本稿注 2

14）百万塔製作のためには轆轤工，その他に伐採・造材など の木作工，鉄工・画工・印刷工などの 各職種の工人が参 画したものと推測される。

15）「観湖雑帳」前揭書に「続紀の尺寸は天平尺なり」とある。

16）小田原市某工房製の木椀木地 100 個を䲄作為儿抽出し, これを神奈川県立工芸指導所木工課で寸度測定をしてる らった。

17）竹内理三氏「日本上代寺院経済史の研究」による，上代技 術労働者の分類（「体系日本史叢畫」10『産業史』1, p. 283）によれば「様工は型・模型を作る。様大工材の様 式を定め…中略…あるいはす心゙てに通じ請負工の意味を 持つことあり」と記され，様工とは一種の設計技術者， 治具・ダージの製作者であったことがうかがえる。

18）遺物の塔にも顔料塗布の跡がらかがえる。狩谷掖斉は, $\lceil …$. 丹碧剝落殆盖……」といっている。

19）鑪・鮫皮・木賊はともに古来加らの研削材で，研削に木
賊を用いることは」倭名類聚抄」百九十九翏漆具の項， 「延喜式」木工寮にあり。

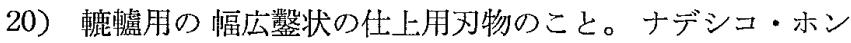
シコ・キサゲなどと呼ぶ。

21）径の小さい深い穴の周壁を抾げるためのリーマー状のュ 具。「偻名類聚抄」に「鉱，毛遅利鑚也」とあり「和漢三 戈図絵」には十字形の恼付のものを図示説明している。

22）轆轤用对物を 鋼材の形で販売する店が，小田原市に一軒 ある。依頼すれば刃物の素形は作ってくれる。

23）轆轠工といわず，一般工人の古来からの習慣であったと

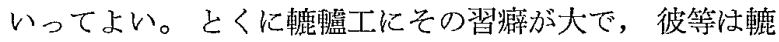
轠工房の傍に靽を備えた鍛治場を持つことを常としてき た。

24）「大日本古文書」：（追加四）正倉院文書東大寺写経所解 案, 同十四 (追加八) 同東大寺司㣰などにあり。

25）「大日本古文書」十六（追加十）正倉院文書作金堂解に 「等轆轠工紀狖万呂」の記載あり。

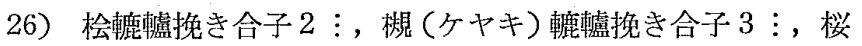
轆轀挽き合子 2 ：など。

27）「大日本古文書」十（追加四）天平 12 年 (748) 正倉院文 書東大寺写経所解案にあり。

28）「倭名類聚抄」第十五第百九十六調度部作具の項。

29）狩谷掖斉「笺註倭名類聚抄」天保 6 年 (1835) 五造作具 「鋋」の項。

30）「齐民要術」種榆白楊第四十六の項, 挟者とは小佳の榆樹 のこょ。

31）「訓蒙図彙」巻之十器用二十八ウ,「和漢三㖪図絵」第二 十四百工具

32）文化朾文化財保護部編「木地師の習俗」 1 三重県・滋賀 県, 2 愛知県・岐阜県, 昭 43 。

33）吉田光邦氏「機械」法政大学出版局（ものと人間の文化 史) 1974.12

34）橋本鉄男氏「ろくろ」法政大学出版局（ものと人閒の文化 史) 1979.1

35）「訓蒙図彙「1668,「和漢三㖪図絵」1712, 「彩画職人部類」 1770 の三書の轆䡷の図のみ軸は中太式, 他はすべて平行 式。

36）ジクネンボりについては「ろくろ」前揭書 p. 303 执よび 第 72 図に説明叔よび説明図があり，加工材を爪に打ち込 むための印き製置となっているが，軸心が同一線上にあ るといら点で心押し機構としての示唆が与えられる。

37）心押し機構については本稿 II の相輪旋削の項において詳 しく述べ，我国に扮ける轆輻と旋盤との関係と西欧に扝 けるそれとを対比して考察する所存である。

38）橋本鉄男氏は「ろくろ」で表 5 の A.B·C·D をそれぞれ 一木式・二木式・三木式・四木式としている。

39）JIS B 6508 「木工用および製材用丸ノコ䍀」囵精度検查 2 主軸の振れ， 3 軸の軸方向の動きの 2 項を準用。 


\section{SY NOPSIS}

UDC : $72.03: 72.022$

EXPERIMENTAL STUDY ON PRODUCTION METHOD OF ONE MILLION WOODEN MINIATURE PAGODA, NAMELY HYAKUMANTO I

-Accuracy of measurment, used face lathe and tools or gauges-

by JUICHIRO NARITA, Lecturer of CHIBA Univ., Member of A.I.J.

We observed and took a measurment of sizes about ONE MILLION WOODEN MINIATURE PAGODAS, namely HYAKUMANTO, left at Horyuji temple.

We manufactured a trial face lathe that had anaxis, and tools or templets in order to acturally produce the HYAKUMANTO, finally checked theire utility. 